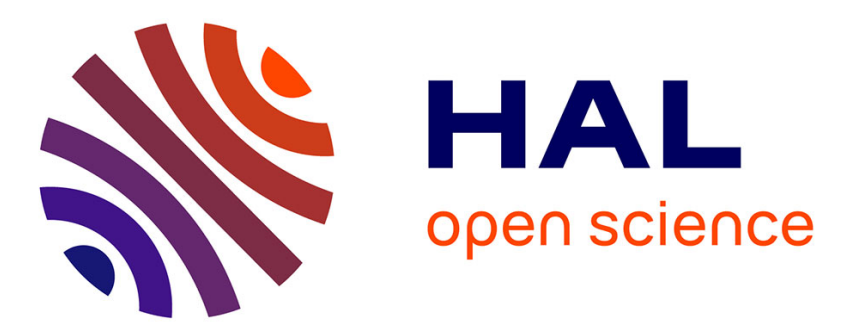

\title{
Impact of the French Infectious Diseases Society's (SPILF) proposals for shorter antibiotic therapies
}

\author{
G. Macheda, A. Luc, G. Béraud, B. Castan, R. Gauzit, P. Lesprit, Pierre
} Tattevin, N. Thilly, C. Pulcini

\section{- To cite this version:}

G. Macheda, A. Luc, G. Béraud, B. Castan, R. Gauzit, et al.. Impact of the French Infectious Diseases Society's (SPILF) proposals for shorter antibiotic therapies. Médecine et Maladies Infectieuses, 2019, 49 (6), pp.456-462. 10.1016/j.medmal.2019.07.005 . hal-02459159

\section{HAL Id: hal-02459159 \\ https://hal.univ-lorraine.fr/hal-02459159}

Submitted on 20 Dec 2021

HAL is a multi-disciplinary open access archive for the deposit and dissemination of scientific research documents, whether they are published or not. The documents may come from teaching and research institutions in France or abroad, or from public or private research centers.
L'archive ouverte pluridisciplinaire HAL, est destinée au dépôt et à la diffusion de documents scientifiques de niveau recherche, publiés ou non, émanant des établissements d'enseignement et de recherche français ou étrangers, des laboratoires publics ou privés.

\section{(c)(1) $\$$}

Distributed under a Creative Commons Attribution - NonCommerciall 4.0 International 


\title{
Impact des propositions pour des antibiothérapies plus courtes de la Société de Pathologie Infectieuse de Langue Française (SPILF)
}

\section{Impact of the French Infectious Diseases Society's (SPILF) proposals for shorter antibiotic}

\author{
therapies
}

\author{
Gabriel Machedaa, Amandine Luc ${ }^{b}$, Guillaume Béraud ${ }^{c, d, e, l}$, Bernard Castan ${ }^{\mathrm{f}, \mathrm{k}}$, \\ Rémy Gauzit ${ }^{g, k}$, Philippe Lesprit ${ }^{h, k}$, Pierre Tattevin ${ }^{i, k}$, Nathalie Thilly ${ }^{b, j}$ et Céline Pulcini ${ }^{a, j, k, k *}$ \\ aUniversité de Lorraine, CHRU-Nancy, Infectious Diseases Department, F-54000 Nancy, \\ France \\ ${ }^{b} \mathrm{CHRU}$ de Nancy, Plateforme d'Aide à la Recherche Clinique, Nancy, France \\ ${ }^{\mathrm{C}} \mathrm{CHU}$ de Poitiers, Médecine Interne et Maladies Infectieuses, Poitiers, France \\ ${ }^{\mathrm{d}}$ Centre de recherche du CHU de Québec- Université Laval, Hôpital Saint-Sacrement, Chemin \\ Sainte-Foy (Québec), Canada \\ eHasselt University, Interuniversity Institute for Biostatistics and statistical Bioinformatics, \\ Censtat, Hasselt, Belgium \\ ${ }^{\mathrm{f}} \mathrm{CH}$ Ajaccio, Unité fonctionnelle d'infectiologie régionale, Ajaccio, France \\ ${ }^{g} \mathrm{AP}-\mathrm{HP}$, hôpitaux universitaires Paris centre-site Cochin, université Paris Descartes, Équipe \\ mobile d'infectiologie, Paris, France

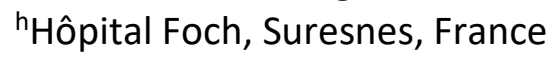 \\ ${ }^{i} \mathrm{CHU}$ de Rennes, hôpital Pontchaillou, Maladies infectieuses et réanimation médicale, \\ Rennes, France \\ JUniversité de Lorraine, APEMAC, F-54000 Nancy, France \\ kMembre de la Société de pathologie infectieuse de langue française (SPILF) \\ 'Membre de l'ESCMID Study Group for Antimicrobial stewardship (ESGAP)
}

*Corresponding author. Centre Hospitalier Régional Universitaire de Nancy, Service de Maladies Infectieuses et Tropicales, Hôpitaux de Brabois, allée du Morvan, 54511 Vandoeuvre-Lès-Nancy, France. Tel: 33-(0)-3-83-15-40-97; Fax: 33-(0)-3-83-15-70-27; E-mail: celine.pulcini@univ-lorraine.fr

Mots clés : bon usage des antibiotiques, antibiotique, recommandations

Keywords: antibiotic stewardship, antibiotic, guidelines 


\section{RESUME}

Objectif. Comparer entre 2016 et 2018 les pratiques des spécialistes français des infections concernant les durées d’antibiothérapie.

Méthodes. Nous avons mené deux enquêtes identiques, une en 2016 et l'autre en 2018, visant les spécialistes hospitaliers des infections (médecins, pharmaciens) ayant une activité de conseil en antibiothérapie au minimum hebdomadaire. Le questionnaire était constitué de 15 vignettes cliniques correspondant à une situation clinique spécifique. La partie $A$ visait à évaluer les durées d'antibiothérapie qu'ils conseillent habituellement aux cliniciens, la partie B recueillait les durées les plus courtes qu'ils seraient prêts à recommander pour les mêmes situations cliniques.

Résultats. Nous avons inclus 165 spécialistes en 2016 et 160 en 2018, majoritairement infectiologues (82\%, 268/325) et/ou membres d'une équipe multidisciplinaire en antibiothérapie $(72 \%, 234 / 325)$. Des durées courtes d'antibiothérapie (par rapport à la littérature) étaient conseillées aux prescripteurs dans plus de $50 \%$ des vignettes par $71 \%$ (105/147) des participants en 2018, contre $46 \%$ (69/150) en $2016(p<0,001)$. Les guides de prescription utilisés par les participants utilisaient des durées d'antibiothérapie fixes dans $77 \%(123 / 160)$ des cas en 2018 contre $21 \%$ (35/165) en 2016. La quasi-totalité (89\%, 131/160) des participants à l'enquête 2018 disait connaître les propositions 2017 de la SPILF.

Conclusion. La publication des propositions SPILF 2017 sur les durées courtes d'antibiothérapie semble avoir eu un impact favorable sur les pratiques des professionnels faisant du conseil en antibiothérapie. 


\section{ABSTRACT}

Objective. To compare the practices of French infection specialists related to antibiotic therapy duration between 2016 and 2018 .

Methods. We conducted two identical surveys (in 2016 and 2018) targeting hospital-based infection specialists (medical physicians, pharmacists) who gave at least weekly advice on antibiotic prescriptions. The questionnaire included 15 clinical vignettes. Part A asked about the durations of antibiotic therapies they would usually advise to prescribers, and part B asked about the shortest duration they would be willing to advise for the same clinical situations.

Results. We included 325 specialists (165 in 2016 and 160 in 2018), mostly infectious disease specialists $(82.4 \%, 268 / 325)$, members of antibiotic stewardship teams in $72 \%(234 / 325)$ of cases. Shorter antibiotic treatments (as compared with the literature) were advised to prescribers in more than half of the vignettes by $71 \%(105 / 147)$ of respondents in 2018 , versus $46 \%(69 / 150)$ in $2016(p<0.001)$. Guidelines used by participants displayed fixed durations for $77 \%(123 / 160)$ of cases in 2018 versus $21 \%(35 / 165)$ in 2016 . Almost all respondents (89\%, 131/160) declared they were aware of the 2017 SPILF's proposal.

Conclusion. The release of guidelines promoting shorter durations of antibiotic therapy seems to have had a favourable impact on practices of specialists giving advice on antibiotic prescriptions. 


\section{INTRODUCTION}

Prescribing the shortest possible antibiotic therapy duration is a key component of the proper use of antibiotics [1-4]. Shorter antibiotic therapies do not negatively impact patients [5-13], and contribute to limiting the risk of antibiotics-related adverse effects. It may also limit the emergence of multidrug-resistant bacteria [14-16]. The French Infectious Diseases Society (French acronym SPILF) published a set of proposals in March 2017, based on a literature review, to promote shorter antibiotic therapies [17].

Most national and international guidelines recommend implementing multidisciplinary antimicrobial stewardship teams in hospital settings [4, 14, 18-20]. These teams are therefore best suited to promote shorter antibiotic therapies. However, no data is available on antibiotic therapy duration recommended to health professionals by infectious disease specialists giving advice on antibiotic prescriptions. We aimed to describe current practices in France, and to assess the potential impact of the 2017 SPILF's proposals.

\section{METHODS}

\section{Study design}

We present the results of two online surveys using the same method and an almost identical questionnaire. Both of these surveys assessed antibiotic therapy durations recommended to health professionals by infection specialists. The complete protocol has already been published [21]. Hospital-based physicians and pharmacists (fully trained or in training) giving at least weekly advice on antibiotic prescriptions (outside of their department) could participate in the survey. The first survey was conducted at the international level between 
September 2016 and December 2016 - the overall results have already been published [21] i.e., before the publication of the SPILF's proposals in March 2017 [17]. The second survey was only conducted in France between the end of January 2018 and March 2018. Invitations to participate were sent using the SPILF's Infectioflash mailing list. The questionnaire was available on the SurveyMonkey ${ }^{\oplus}$ platform.

\section{Questionnaire}

The questionnaire was designed by a multidisciplinary group of experts in infectious diseases, microbiology, and public health, and was based on a literature review [17]. The questionnaire was first pilot tested with members of the SPILF's and ESCMID's working groups on antibiotic stewardship to check for clarity.

The questionnaire was divided into three parts (the English version of the complete questionnaire is available upon request to Pulcini et al. [21]). The first part aimed to collect information on respondents' characteristics. The two subsequent parts assessed the usual practice of respondents in terms of antibiotic therapy duration recommendations made to health professionals for a specific clinical situation (A), and the shortest total duration they would be willing to recommend for the same cases (B). Parts A and B used clinical vignettes each one describing a specific clinical situation, assuming for each a "best case scenario", i.e. that an appropriate antibiotic was prescribed (in terms of choice of molecule, dosing regimen, route of administration) and that the outcome was favorable with this treatment. The questionnaire of the second survey (2018) was identical to the one used for the first survey (2016), but it was translated into French and included four additional questions to assess knowledge and compliance with the proposals formulated by the SPILF in 2017 for shorter 
antibiotic therapies [17]. The invitation mail only informed participants that the survey was about antibiotic therapy duration, with no mention of shorter duration.

As participation was anonymous, we cannot know whether some respondents to the 2016 survey also took part in the 2018 survey. No compensation was given to respondents.

\section{Statistical analyses}

Respondents' demographic and professional characteristics were first described as numbers and percentages. For each clinical vignette, the usually recommended duration of antibiotic therapy and the shortest duration that respondents were willing to recommend were presented as medians (days). For each clinical situation, short treatment durations were defined based on a literature review [17] and a consensus among all authors (details available in English from Pulcini et al. [21]). For each clinical vignette and each situation (duration of antibiotic therapy usually recommended or the shortest duration that respondents were willing to recommend), the percentages of respondents recommending short treatment durations as previously defined were calculated for 2016 and 2018 and then compared using the Chi-square test. Percentages of respondents usually recommending short antibiotic therapies for at least 50\% of the vignettes were calculated for 2016 and 2018 and then compared. Respondents who failed to respond to more than seven clinical vignettes were excluded from the latter analysis. All comparisons were performed using the Chi-square test, with a significance threshold set at $5 \%$. Analyses were performed using the SAS software, version 9.4 (SAS Institute, Inc., Cary, NC).

\section{RESULTS}




\section{Sample characteristics}

The total number of respondents to the first survey (2016) was 165 and 160 to the second survey (2018). The main characteristics of respondents are detailed in Table I. Professional characteristics were comparable in the two surveys, except for the "Member of an antimicrobial stewardship team" characteristic (66\% in 2018 versus $79 \%$ in $2016, p=0.01$ ). However, a higher proportion of respondents in 2018 than 2016 declared that the guidelines they refer to display fixed durations of antibiotic therapy (77\% in 2018 versus $21 \%$ in 2016 , $p<0.001)$. A lower proportion of respondents practiced in university hospitals in $2018(49 \%)$ than 2016 (60\%). Almost all respondents (89\%) to the 2018 survey declared being aware of the 2017 proposals of the SPILF, and most of them declared complying with such proposals in their daily practice.

\section{Usual practice and shortest durations recommended}

The respondents' usual recommendations to health professionals regarding durations of antibiotic therapy and the shortest durations they would be willing to recommend for the same clinical situations are presented in Tables II and III. Medians related to usually recommended durations were shorter in 2018 than 2016 for 26\% (4/15) of the vignettes and identical for the remaining vignettes. The same findings were observed for the shortest durations that respondents would be willing to recommend (shorter medians for $26 \%$ of the vignettes in 2018 versus 2016), with for instance a halved antibiotic therapy duration for acute pyelonephritis at risk of complication in women.

\section{Comparison of practices between the two surveys}

Percentages of respondents usually recommending a short treatment duration in 2016 and 2018, as well as comparisons, are presented in Table IV. Recommendations for short antibiotic 
therapies highly varied by vignette, ranging from $<3 \%$ of cases for the erysipelas vignette to $>97 \%$ of cases for Escherichia coli uncomplicated spondylodiscitis in a patient without orthopedic implant. Respondents to the 2018 survey more often recommended short antibiotic therapies for $46 \%$ of the vignettes (7/15) compared with 2016 , with only one case of longer antibiotic therapy recommended (Staphylococcus aureus uncomplicated catheterrelated bacteremia). The proportion of respondents who recommended a short antibiotic therapy for at least 50\% of the vignettes was $71 \%$ in 2018 versus $46 \%$ in $2016(p<0.001)$.

Table $V$ details the differences between 2016 and 2018 for the shortest durations that respondents would be willing to recommend. Respondents to the 2018 survey recommended short antibiotic therapies significantly more often than respondents to the 2016 survey for $40 \%$ of the vignettes $(6 / 15)$.

\section{DISCUSSION}

Among all respondents to both surveys, $82 \%$ were infectious disease specialists and $72 \%$ were members of a multidisciplinary antimicrobial stewardship team. Almost $90 \%$ of respondents to the 2018 survey were aware of the SPILF's 2017 proposals for shorter antibiotic therapies [17]; $84 \%$ declared taking them into consideration when adapting treatment duration in their health facility and $90 \%$ in their daily practice. Seventy-seven per cent of respondents to the 2018 survey declared that the guidelines they referred to displayed fixed antibiotic therapy durations, as opposed to ranges. Treatment durations recommended by the 2018 respondents were substantially shorter than those recommended by respondents in 2016, even though the situation varied depending on the clinical vignettes. These findings thus 
suggest that the 2017 SPILF's proposals had a significant impact, although no causal relation can be confirmed.

Short durations are heterogeneously complied with depending on the clinical situation, even though the latter are all mentioned in the 2017 SPILF's proposals. Ninety-three per cent of respondents recommended short treatment durations for diabetic foot ulcer and osteitis, without any indication for surgery; $95 \%$ for uncomplicated acute pyelonephritis treated with fluoroquinolones in a women; but only $24.5 \%$ for an outpatient with a community-acquired uncomplicated acute pneumonia; and $3 \%$ for uncomplicated erysipelas. The difficult clinical reevaluation associated with outpatient care (pneumonia, erysipelas) may lead physicians to recommend short treatment durations less frequently. Obstacles to the recommendation of short treatment duration depending on clinical situations should be further evaluated. Our data may however already be used to adjust the initial and continuing training of members of multidisciplinary antimicrobial stewardship teams (especially infectious disease specialists).

Our study presents original findings, but has several limitations. We could not calculate any response rate (for lack of a denominator, i.e. reliable data on the total number of eligible people who received the survey), but we obviously could not include all lead physicians or members of French multidisciplinary antimicrobial stewardship teams, and most respondents (54\% for both studies) practiced in university hospitals. We therefore could not apply our results to the whole of France. Respondents may have been the best motivated and knowledgeable health professionals on the subject; our results may therefore be an optimistic presentation of the actual situation. Also, the international global results of our first survey [21] were available as "Advance Access only" on January 16, 2018, i.e. at the time of the second survey. We deliberately did not include such information in the invitation mail, but the 
answers of respondents who had consulted such results may be biased. Although the use of clinical vignettes has been approved in assessing medical practices [21], it does not necessarily reflect the actual practices of respondents.

\section{CONCLUSION}

Our study results suggest that most infection specialists in France take into consideration the latest proposals from the SPILF on shorter antibiotic therapies.

\section{Funding}

The authors did not receive any funding.

\section{Disclosure of interests}

The authors declare no conflict of interests. 


\section{References}

1. WHO. Global Action Plan on Antimicrobial Resistance. 2015. http://www.wpro.who.int/entity/drug_resistance/resources/global_action_plan_eng.p df.

2. ECDC. Proposals for EU Guidelines on the Prudent Use of Antimicrobials in Humans. 2017. https://ecdc.europa.eu/en/publications-data/proposals-euguidelines- prudentuse-antimicrobials-humans.

3. EU. EU Guidelines for the Prudent Use of Antimicrobials in Human Health. 2017. https://ec.europa.eu/health/amr/sites/amr/files/amr_guidelines_prude nt_use_en.pdf.

4. BSAC. Antimicrobial Stewardship From principles to practice. 2018. http://www.bsac.org.uk/.

5. Llewelyn MJ, Fitzpatrick JM, Darwin E, SarahTonkin-Crine null, Gorton C, Paul J, et al. The antibiotic course has had its day. BMJ 2017;358:j3418.

6. Havey TC, Fowler RA, Daneman N. Duration of antibiotic therapy for bacteremia: a systematic review and meta-analysis. Crit Care 2011;15(6):R267.

7. Moussaoui el R, de Borgie CAJM, van den Broek $P$, Hustinx WN, Bresser $P$, van den Berk $G E L$, et al. Effectiveness of discontinuing antibiotic treatment after three days versus eight days in mild to moderate-severe community acquired pneumonia: randomised, double blind study. BMJ 2006;332(7554):1355-60.

8. Eliakim-Raz N, Yahav D, Paul M, Leibovici L. Duration of antibiotic treatment for acute pyelonephritis and septic urinary tract infection-- 7 days or less versus longer treatment: systematic review and meta-analysis of randomized controlled trials. J Antimicrob Chemother 2013;68(10):2183-91.

9. Basoli A, Chirletti P, Cirino E, D'Ovidio NG, Doglietto GB, Giglio D, et al. A prospective, double-blind, multicenter, randomized trial comparing ertapenem 3 vs $>0 r=5$ days in community-acquired intraabdominal infection. J Gastrointest Surg 2008;12(3):592-600.

10. Karageorgopoulos DE, Valkimadi PE, Kapaskelis A, Rafailidis PI, Falagas ME. Short versus long duration of antibiotic therapy for bacterial meningitis: a meta-analysis of randomised controlled trials in children. Arch Dis Child 2009;94(8):607-14.

11. Ellis-Pegler R, Galler L, Roberts S, Thomas M, Woodhouse A. Three days of intravenous benzyl penicillin treatment of meningococcal disease in adults. Clin Infect Dis2003;37(5):658-62.

12. Dimopoulos G, Matthaiou DK, Karageorgopoulos DE, Grammatikos AP, Athanassa Z, Falagas ME. Short- versus long-course antibacterial therapy for community-acquired pneumonia: a meta-analysis. Drugs. 2008;68(13):1841-54. 
13. Li JZ, Winston LG, Moore DH, Bent S. Efficacy of short-course antibiotic regimens for community-acquired pneumonia: a meta-analysis. Am J Med 2007;120(9):783-90.

14. Barlam TF, Cosgrove SE, Abbo LM, MacDougall C, Schuetz AN, Septimus EJ, et al. Implementing an Antibiotic Stewardship Program: Guidelines by the Infectious Diseases Society of America and the Society for Healthcare Epidemiology of America. Clin Infect Dis 2016;62(10):e51-77.

15. Armand-Lefèvre L, Angebault C, Barbier F, Hamelet E, Defrance G, Ruppé $E$, et al. Emergence of imipenem-resistant gram-negative bacilli in intestinal flora of intensive care patients. Antimicrob Agents Chemother 2013;57(3):1488-95.

16. Harbarth S, Samore MH, Lichtenberg D, Carmeli Y. Prolonged antibiotic prophylaxis after cardiovascular surgery and its effect on surgical site infections and antimicrobial resistance. Circulation 2000;101(25):2916-21.

17. Wintenberger C, Guery B, Bonnet E, Castan B, Cohen R, Diamantis S, et al. Proposal for shorter antibiotic therapies. Med Mal Infect 2017;47(2):92-141.

18. NICE. Antimicrobial Stewardship: Systems and Processes for Effective Antimicrobial Medicine Use. 2015. https://www.nice.org.uk/guidance/ng15

19. Pulcini C, Morel CM, Tacconelli E, Beovic B, de With K, Goossens H, et al. Human resources estimates and funding for antibiotic stewardship teams are urgently needed. Clin Microbiol Infect 2017;23(11):785-7.

20. Pulcini C, Binda F, Lamkang AS, Trett A, Charani E, Goff DA, et al. Developing core elements and checklist items for global hospital antimicrobial stewardship programmes: a consensus approach. Clin Microbiol Infect [Internet] 2018; Available from: http://dx.doi.org/10.1016/j.cmi.2018.03.033

21. Macheda G, Dyar OJ, Luc A, Beovic B, Béraud G, Castan B, et al. Are infection specialists recommending short antibiotic treatment durations? An ESCMID international crosssectional survey. J Antimicrob Chemother 2018;73(4):1084-90. 
Tableau I. Caractéristiques des participants / Table I. Characteristics of respondents

\begin{tabular}{|c|c|c|c|c|c|}
\hline & & \multicolumn{4}{|c|}{ Respondents } \\
\hline & & \multicolumn{2}{|c|}{2016} & \multicolumn{2}{|c|}{2018} \\
\hline & & $\mathrm{N}$ & $\%$ & $\mathrm{~N}$ & $\%$ \\
\hline \multirow{2}{*}{$\begin{array}{l}\text { Frequency of antibiotic } \\
\text { prescription advice to } \\
\text { colleagues or family } \\
\text { physicians }\end{array}$} & Yes, every day & 110 & 66.7 & 108 & 67.5 \\
\hline & Yes, at least once a week & 55 & 33.3 & 52 & 32.5 \\
\hline \multirow[t]{3}{*}{ Sex } & Male & 89 & 54.3 & 84 & 52.8 \\
\hline & Female & 75 & 45.7 & 75 & 47.2 \\
\hline & Missing data & 1 & & 1 & \\
\hline \multirow[t]{4}{*}{ Age } & $<30$ years & 16 & 9.8 & 13 & 8.1 \\
\hline & $30-50$ years & 113 & 68.9 & 108 & 67.5 \\
\hline & $>50$ years & 35 & 21.3 & 39 & 24.4 \\
\hline & Missing data & 1 & & & \\
\hline \multirow[t]{5}{*}{ Health facility } & University hospital & 98 & 59.8 & 78 & 49.1 \\
\hline & Other public hospital & 53 & 32.3 & 67 & 42.1 \\
\hline & Private hospital/clinic & 11 & 6.7 & 10 & 6.3 \\
\hline & Other & 2 & 1.2 & 4 & 2.5 \\
\hline & Missing data & 1 & & 1 & \\
\hline \multirow[t]{5}{*}{ Specialty } & Infectious diseases & 134 & 81.7 & 134 & 83.8 \\
\hline & Microbiology & 6 & 3.7 & 2 & 1.3 \\
\hline & Pharmacy & 1 & 0.6 & 2 & 1.3 \\
\hline & Other & $23^{a}$ & 14.0 & $22^{b}$ & 13.8 \\
\hline & Missing data & 1 & & & \\
\hline \multirow{8}{*}{$\begin{array}{l}\text { Years of practice within } \\
\text { current specialty }\end{array}$} & $0-5$ years & 44 & 26.8 & 47 & 29.4 \\
\hline & $6-10$ years & 31 & 18.9 & 41 & 25.6 \\
\hline & $>10$ years & 73 & 44.5 & 61 & 38.1 \\
\hline & I am currently undertaking & & & & \\
\hline & my specialty training & 15 & 9.1 & 11 & 6.9 \\
\hline & I haven't started my & & & & \\
\hline & specialty training & 1 & 0.6 & & \\
\hline & Missing data & 1 & & & \\
\hline \multirow{3}{*}{$\begin{array}{l}\text { Member of an antimicrobial } \\
\text { stewardship team }\end{array}$} & Yes & 128 & 79.0 & 106 & 66.3 \\
\hline & No & 34 & 21.0 & 54 & 33.8 \\
\hline & Missing data & 3 & & & \\
\hline \multirow{3}{*}{$\begin{array}{l}\text { Presentation of durations of } \\
\text { antibiotic therapy in the } \\
\text { guidelines referred to }\end{array}$} & Range (e.g. 5-10 days) & 130 & 78.8 & 36 & \multirow{3}{*}{$\begin{array}{l}22.6 \\
77.4\end{array}$} \\
\hline & Fixed duration (e.g., 5 days) & 35 & 21.2 & 123 & \\
\hline & Missing data & & & 1 & \\
\hline \multirow{3}{*}{$\begin{array}{l}\text { Knowledge of the } 2017 \text { SPILF's } \\
\text { proposals for shorter } \\
\text { antibiotic therapies* }\end{array}$} & Yes & & & 131 & \multirow{3}{*}{$\begin{array}{l}89.1 \\
10.9\end{array}$} \\
\hline & No & & & 16 & \\
\hline & Missing data & & & 13 & \\
\hline
\end{tabular}


Consideration of the SPILF's proposals when adapting treatment durations from local/regional guidelines*

Use of short treatment durations mentioned in the SPILF's proposals in your daily practice*

a Main specialties: intensive care medicine (39.1\%, 9/23), pedia 3/23)

${ }^{\mathrm{b}}$ Main specialties: pediatrics $(27.2 \%, 6 / 22)$, general medicine $(18.1 \%, 4 / 22)$, intensive care medicine $(13.6 \%$,

${ }^{b}$ Main

* Question only asked in 2018

No, we are not planning on integrating such proposals in our guidelines No, but we are planning to $1 \quad 0.7$ Yes, we shortened antibiotic therapy durations Yes, we no longer use ranges of treatment duration Missing data Yes, sometimes $\quad 13 \quad 9.9$ Yes, often $\quad 61 \quad 46.6$ Yes, almost all the time $\quad 57 \quad 43.5$ $0 \quad 0$ No 0

(13\%,
0 
Tableau II. Durées d'antibiothérapie habituellement recommandées proposées par les participants pour les 15 vignettes cliniques (enquêtes 2016 et 2018)

Table II. Antibiotic therapy duration usually recommended for the 15 clinical vignettes (2016 and 2018 surveys)

\begin{tabular}{|c|c|c|c|c|c|c|c|c|}
\hline \multirow[b]{2}{*}{ Clinical vignette } & \multicolumn{4}{|c|}{$\begin{array}{l}\text { Duration of antibiotic therapy usually } \\
\text { recommended (2016) }\end{array}$} & \multicolumn{4}{|c|}{$\begin{array}{l}\text { Duration of antibiotic therapy usually } \\
\text { recommended (2018) }\end{array}$} \\
\hline & $\mathrm{N}$ & $\begin{array}{l}\text { Media } \\
n \\
\text { (days) }\end{array}$ & $\begin{array}{c}\text { Would } \\
\text { not } \\
\text { prescribe } \\
\text { an } \\
\text { antibiotic } \\
(\%)\end{array}$ & $\begin{array}{c}\text { Not } \\
\text { applicable } \\
\text { to my } \\
\text { practice } \\
(\%)\end{array}$ & $\mathrm{N}$ & $\begin{array}{l}\text { Median } \\
\text { (days) }\end{array}$ & $\begin{array}{l}\text { Would not } \\
\text { prescribe } \\
\text { an } \\
\text { antibiotic } \\
\text { (\%) }\end{array}$ & $\begin{array}{c}\text { Not } \\
\text { applicable } \\
\text { to my } \\
\text { practice } \\
(\%)\end{array}$ \\
\hline $\begin{array}{l}\text { Child or adolescent with Neisseria } \\
\text { meningitidis meningitis }\end{array}$ & 156 & 7 & 0 & 5.8 & 152 & 5 & 2.0 & 7.2 \\
\hline $\begin{array}{l}\text { Patient with acute cholecystitis, } \\
\text { successfully and rapidly treated by } \\
\text { endoscopic biliary drainage }\end{array}$ & 156 & 7 & 0 & 4.5 & 150 & 5 & 1.3 & 5.3 \\
\hline $\begin{array}{l}\text { Patient with diffuse peritonitis, with } \\
\text { adequate and rapid surgery }\end{array}$ & 155 & 7 & 0 & 4.5 & 150 & 5 & 0.7 & 3.3 \\
\hline $\begin{array}{l}\text { Woman with uncomplicated acute } \\
\text { pyelonephritis (if a fluoroquinolone } \\
\text { is prescribed) }\end{array}$ & 156 & 7 & 0 & 2.6 & 151 & 7 & 0 & 1.3 \\
\hline $\begin{array}{l}\text { Woman with acute pyelonephritis at } \\
\text { risk of complication }\end{array}$ & 156 & 10 & 0 & 2.6 & 150 & 10 & 0 & 2.0 \\
\hline $\begin{array}{l}\text { Outpatient with community- } \\
\text { acquired uncomplicated acute } \\
\text { pneumonia }\end{array}$ & 153 & 7 & 0 & 1.3 & 148 & 7 & 0 & 1.4 \\
\hline $\begin{array}{l}\text { Patient with an acute exacerbation } \\
\text { of COPD }\end{array}$ & 153 & 5 & 4.6 & 3.9 & 150 & 5 & 2.7 & 5.3 \\
\hline $\begin{array}{l}\text { Patient with uncomplicated } \\
\text { catheter-related Staphylococcus } \\
\text { aureus bacteremia }\end{array}$ & 153 & 14 & 0 & 1.3 & 148 & 14 & 0 & 0.7 \\
\hline $\begin{array}{l}\text { Patient with uncomplicated } \\
\text { catheter-related Klebsiella } \\
\text { pneumoniae bacteremia }\end{array}$ & 152 & 7 & 0 & 1.3 & 149 & 7 & 0 & 1.3 \\
\hline $\begin{array}{l}\text { Patient with uncomplicated } \\
\text { Escherichia coli spondylodiscitis, } \\
\text { without orthopedic implant }\end{array}$ & 153 & 42 & 1.3 & 2.6 & 150 & 42 & 0 & 4.0 \\
\hline & 152 & 42 & 1.3 & 9.9 & 147 & 42 & 0 & 8.2 \\
\hline
\end{tabular}


Patient with diabetic foot ulcer and osteitis, not eligible for surgery

Patient with uncomplicated

staphylococcal prosthetic infection,

managed with one-stage exchange

Patient with uncomplicated

152

10

0

$\begin{array}{lll}0.7 & 149 & 7\end{array}$

0

0.7

erysipelas

Child ( $>2$ years) with a first episode

152

5

11.8

18.4

148

5

6.8

28.4

of purulent acute otitis media

$151 \quad 7$

6.0

6.6

148

7

4.0

7.4

sinusitis of suspected bacterial origin

COPD: chronic obstructive pulmonary disease 
Tableau III. Durées les plus courtes proposées par les participants pour les 15 vignettes cliniques (enquêtes 2016 et 2018)

Table III. Shortest durations the respondents would be willing to recommend for the 15 clinical vignettes (2016 and 2018 surveys)

\begin{tabular}{|c|c|c|c|c|c|c|c|c|}
\hline \multirow[b]{2}{*}{ Clinical vignette } & \multicolumn{4}{|c|}{$\begin{array}{l}\text { Shortest duration recommended } \\
\text { (2016) }\end{array}$} & \multicolumn{4}{|c|}{ Shortest duration recommended (2018) } \\
\hline & $\mathrm{N}$ & $\begin{array}{l}\text { Media } \\
\mathrm{n} \\
\text { (days) }\end{array}$ & $\begin{array}{c}\text { Would } \\
\text { not } \\
\text { prescribe } \\
\text { an } \\
\text { antibiotic } \\
(\%)\end{array}$ & $\begin{array}{l}\text { Not } \\
\text { applicable } \\
\text { to my } \\
\text { practice } \\
(\%)\end{array}$ & $\mathrm{N}$ & $\begin{array}{l}\text { Median } \\
\text { (days) }\end{array}$ & $\begin{array}{l}\text { Would not } \\
\text { prescribe } \\
\text { an } \\
\text { antibiotic } \\
\text { (\%) }\end{array}$ & $\begin{array}{c}\text { Not } \\
\text { applicable } \\
\text { to my } \\
\text { practice } \\
(\%)\end{array}$ \\
\hline $\begin{array}{l}\text { Child or adolescent with Neisseria } \\
\text { meningitidis meningitis }\end{array}$ & 146 & 5 & 0 & 4.1 & 144 & 5 & 0.7 & 6.3 \\
\hline $\begin{array}{l}\text { Patient with acute cholecystitis, } \\
\text { successfully and rapidly treated by } \\
\text { endoscopic biliary drainage }\end{array}$ & 144 & 5 & 0.7 & 2.1 & 143 & 3 & 2.8 & 4.2 \\
\hline $\begin{array}{l}\text { Patient with diffuse peritonitis, with } \\
\text { adequate and rapid surgery }\end{array}$ & 145 & 5 & 0 & 3.4 & 143 & 4 & 0.7 & 3.5 \\
\hline $\begin{array}{l}\text { Woman with uncomplicated acute } \\
\text { pyelonephritis (if a fluoroquinolone } \\
\text { is prescribed) }\end{array}$ & 145 & 7 & 0 & 2.1 & 143 & 7 & 0 & 1.4 \\
\hline $\begin{array}{l}\text { Woman with acute pyelonephritis at } \\
\text { risk of complication }\end{array}$ & 145 & 14 & 0 & 2.1 & 143 & 7 & 0 & 2.1 \\
\hline $\begin{array}{l}\text { Outpatient with community- } \\
\text { acquired uncomplicated acute } \\
\text { pneumonia }\end{array}$ & 142 & 5 & 7.0 & 3.5 & 144 & 5 & 0.7 & 0.7 \\
\hline $\begin{array}{l}\text { Patient with an acute exacerbation } \\
\text { of COPD }\end{array}$ & 146 & 5 & 0 & 0 & 144 & 5 & 6.9 & 4.9 \\
\hline $\begin{array}{l}\text { Patient with uncomplicated } \\
\text { catheter-related Staphylococcus } \\
\text { aureus bacteremia }\end{array}$ & 146 & 10 & 0.7 & 0 & 143 & 10 & 0 & 0.7 \\
\hline $\begin{array}{l}\text { Patient with uncomplicated } \\
\text { catheter-related Klebsiella } \\
\text { pneumoniae bacteremia }\end{array}$ & 143 & 7 & 1.4 & 0 & 142 & 7 & 0 & 1.4 \\
\hline $\begin{array}{l}\text { Patient with uncomplicated } \\
\text { Escherichia coli spondylodiscitis, } \\
\text { without orthopedic implant }\end{array}$ & 146 & 42 & 0 & 3.4 & 144 & 42 & 0 & 4.2 \\
\hline & 142 & 42 & 1.4 & 8.5 & 141 & 35 & 0.7 & 6.4 \\
\hline
\end{tabular}


Patient with diabetic foot ulcer and osteitis, not eligible for surgery

Patient with uncomplicated

managed with one-stage exchange

Patient with uncomplicated

142

7

0

$0 \quad 144$

0

0.7

erysipelas

Child ( $>2$ years) with a first episode

143

5

15.4

15.4

144

5

9.0

27.1

of purulent acute otitis media

144

9.7

6.3

143

5

4.9 
Tableau IV. Comparaison 2016-2018 du pourcentage de traitements courts recommandés pour chaque vignette (pratique habituelle)

Table IV. 2016-2018 comparison of percentages of short treatments recommended for each vignette (usual practice) 


\begin{tabular}{|c|c|c|c|c|c|}
\hline & \multicolumn{2}{|c|}{$\begin{array}{c}2016 \\
N=165\end{array}$} & \multicolumn{2}{|c|}{$\begin{array}{c}2018 \\
N=160\end{array}$} & \multirow[b]{2}{*}{$p$} \\
\hline & $\mathrm{N}$ & $\%$ & $\mathrm{~N}$ & $\%$ & \\
\hline \multicolumn{6}{|l|}{ Child or adolescent with Neisseria meningitidis meningitis } \\
\hline Long treatment & 78 & 53.1 & 66 & 47.8 & \multirow{3}{*}{0.377} \\
\hline Short treatment & 69 & 46.9 & 72 & 52.2 & \\
\hline Missing data & 18 & & 22 & & \\
\hline \multicolumn{6}{|l|}{$\begin{array}{l}\text { Patient with acute cholecystitis, successfully and rapidly } \\
\text { treated by endoscopic biliary drainage }\end{array}$} \\
\hline Long treatment & 136 & 91.3 & 95 & 67.9 & \multirow[t]{3}{*}{$<0.001$} \\
\hline Short treatment & 13 & 8.7 & 45 & 32.1 & \\
\hline Missing data & 16 & & 20 & & \\
\hline \multicolumn{6}{|l|}{$\begin{array}{l}\text { Patient with diffuse peritonitis, with adequate and rapid } \\
\text { surgery }\end{array}$} \\
\hline Long treatment & 127 & 85.8 & 110 & 76.4 & \multirow{3}{*}{0.039} \\
\hline Short treatment & 21 & 14.2 & 34 & 23.6 & \\
\hline Missing data & 17 & & 16 & & \\
\hline \multicolumn{6}{|l|}{$\begin{array}{l}\text { Woman with uncomplicated acute pyelonephritis (if a } \\
\text { fluoroquinolone is prescribed) }\end{array}$} \\
\hline Long treatment & 13 & 8.6 & 7 & 4.7 & \multirow{3}{*}{0.179} \\
\hline Short treatment & 139 & 91.4 & 142 & 95.3 & \\
\hline $\begin{array}{l}\text { Snort treatment } \\
\text { Missing data }\end{array}$ & 13 & & 11 & & \\
\hline \multicolumn{6}{|l|}{ Woman with acute pyelonephritis at risk of complication } \\
\hline Long treatment & 75 & 49.3 & 26 & 17.7 & \multirow{3}{*}{$<0.001$} \\
\hline Short treatment & 77 & 50.7 & 121 & 82.3 & \\
\hline Missing data & 13 & & 13 & & \\
\hline \multicolumn{6}{|l|}{$\begin{array}{l}\text { Outpatient with community-acquired uncomplicated } \\
\text { acute pneumonia }\end{array}$} \\
\hline $\begin{array}{l}\text { acute pheumonia } \\
\text { Long treatment }\end{array}$ & 133 & 88.1 & 110 & 75.3 & \multirow{3}{*}{0.004} \\
\hline Short treatment & 18 & 11.9 & 36 & 24.7 & \\
\hline Missing data & 14 & & 14 & & \\
\hline \multicolumn{6}{|l|}{ Patient with an acute exacerbation of COPD } \\
\hline Long treatment & 55 & 39.3 & 47 & 34.1 & \multirow{3}{*}{0.365} \\
\hline Short treatment & 85 & 60.7 & 91 & 65.9 & \\
\hline Missing data & 25 & & 22 & & \\
\hline \multicolumn{6}{|l|}{ Patient with uncomplicated catheter-related } \\
\hline Staphylococcus aureus bacteremia & 91 & 60.3 & 108 & 73.5 & \multirow{4}{*}{0.015} \\
\hline Long treatment & 60 & 39.7 & 39 & 26.5 & \\
\hline Short treatment & 14 & & 13 & & \\
\hline $\begin{array}{l}\text { Missing data } \\
\text { Patient with uncomplicated catheter-related Klebsiella }\end{array}$ & & & & & \\
\hline \multicolumn{6}{|l|}{$\begin{array}{l}\text { Patient with uncomplicated catheter-related Klebsiella } \\
\text { pneumoniae bacteremia }\end{array}$} \\
\hline Long treatment & 70 & $\begin{array}{l}46.7 \\
522\end{array}$ & $\begin{array}{c}41 \\
106\end{array}$ & 27.9 & \multirow{3}{*}{$<0.001$} \\
\hline Short treatment & 80 & 53.3 & 106 & 72.1 & \\
\hline Missing data & 15 & & 13 & & \\
\hline \multicolumn{6}{|l|}{$\begin{array}{l}\text { Patient with uncomplicated Escherichia coli } \\
\text { spondylodiscitis, without orthopedic implant }\end{array}$} \\
\hline Long treatment & 4 & 2.7 & 3 & 2.1 & \multirow[t]{3}{*}{1} \\
\hline Short treatment & 143 & 97.3 & 141 & 97.9 & \\
\hline Missing data & 18 & & 16 & & \\
\hline Patient with diabetic foot ulcer and osteitis, not eligible & & 20.0 & & 6.7 & 0.001 \\
\hline for surgery & 27 & 80.0 & 9 & 93.3 & \\
\hline
\end{tabular}


Long treatment

Missing data

Patient with uncomplicated staphylococcal prosthetic

infection, managed with one-stage exchange

Long treatment

Short treatment

57

$\begin{array}{ccc}40.7 & 33 & 24.3 \\ 59.3 & 103 & 75.7 \\ & 24 & \end{array}$

0.003

Missing data

83

25

147

97.

Long treatment

Short treatment

4

Missing data

14

2.6

144

97.3

2.7

Child ( $>2$ years) with a first episode of purulent acute

otitis media

Long treatment

Short treatment

44

62

41.5

58.5

4

12

Missing data

59

Adult with uncomplicated maxillary sinusitis of suspected bacterial origin

Long treatment

Short treatment

COPD: chronic obstructive pulmonary disease 
Table V. 2016-2018 comparison of percentages of shortened durations for each vignette (shortest possible duration)

Tableau V. Comparaison 2016-2018 du pourcentage de traitements courts à chaque vignette (durée la plus courte possible)

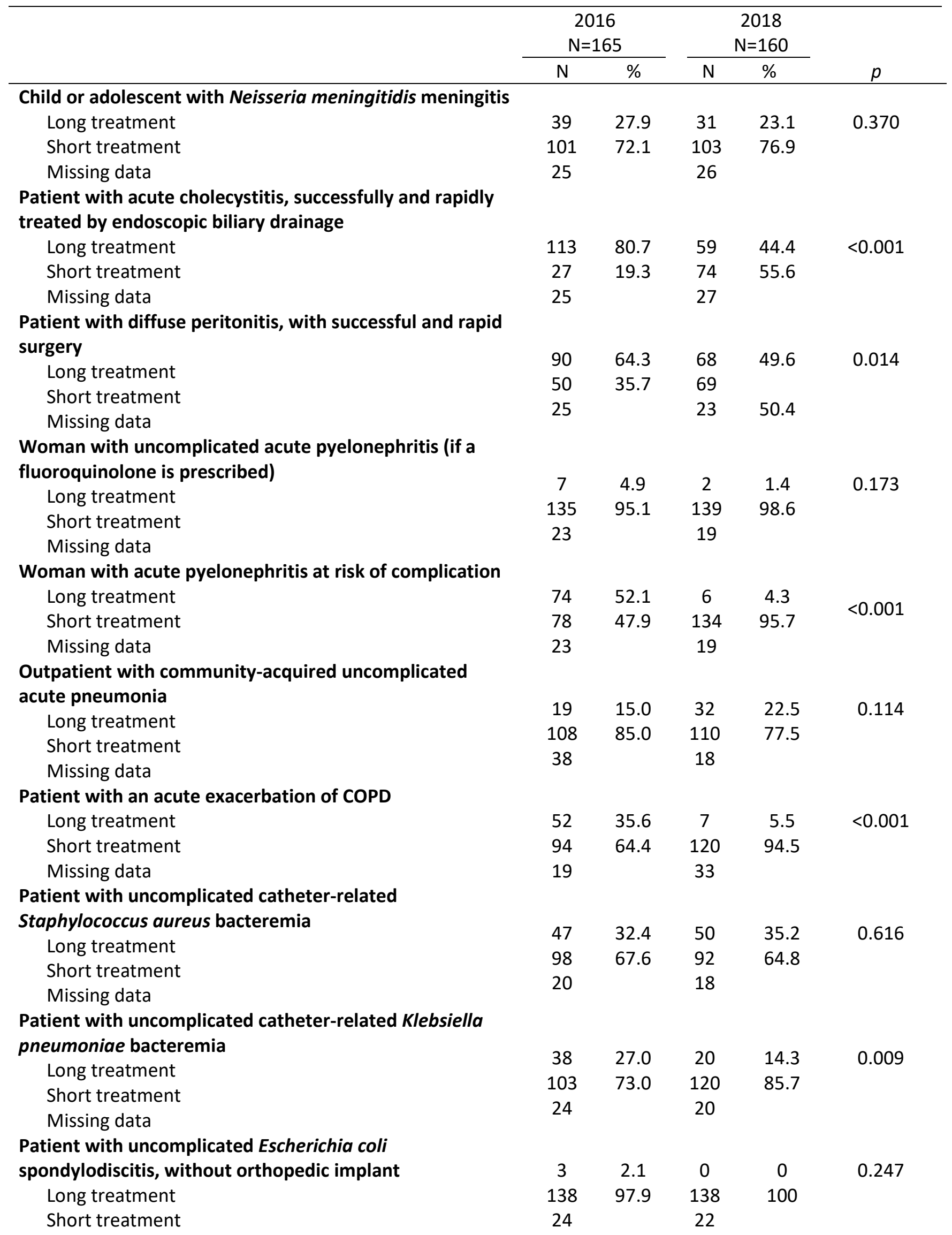


Missing data

Patient with diabetic foot ulcer and osteitis, not eligible for surgery

Long treatment

Short treatment

Missing data

Patient with uncomplicated staphylococcal prosthetic

infection, managed with one-stage exchange

Long treatment

Short treatment

Missing data

Patient with uncomplicated erysipelas

Long treatment

Short treatment

Missing data

Child (>2 years) with a first episode of purulent acute otitis media

Long treatment

Short treatment

Missing data

Adult with uncomplicated maxillary sinusitis of suspected bacterial origin

Long treatment

Short treatment

Missing data

COPD: chronic obstructive pulmonary disease
14

114

$\begin{array}{cccc}10.9 & 1 & 0.8 & <0.001 \\ 89.1 & 130 & 99.2 & \\ & 29 & & \end{array}$

17

117

12.7

\section{7}

12.6

0.981

31

87.3

118

87.4

25

102

71.8

100

69.9

0.724

40

28.2

43

30.1

23

23

17

17.2

14

15.2

0.714

82

82.8

78

84.8

66

68

31

25.6

28

21.9

0.487

$\begin{array}{lll}90 & 74.4 & 100\end{array}$

78.1

32

44

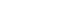

